DOI: https://doi.org/10.4796o/2303-7431.24.2020.29

UDK: 821.163.42.09-1 Kramar I.

Izvorni znanstveni članak

Primljen 13. XI. 2020.

Prihvaćen 7. IV. 2021.

Marina KlJajo-Radić

Sveučilište u Mostaru, Filozofski fakultet

marina.kljajo@ff.sum.ba

\title{
DUHOVNO SUZVUČJE LJUBAVI
}

\section{Sažetak}

Poezija Ivana Kramara u dvjema novim zbirkama moderna je poetika u kojoj su duhovnost i ljubav u čvrstoj sprezi s prirodom i ljepotom. Pjesnička riječ živo korespondira s lirskim i refleksivnim silnicama Kramarove poezije jer je moderni stih srastao s impresijama i ekspresijama njegova nutarnjeg bivstva. Stilski jednostavnim, a opet pomno probranim riječima i poetskim slikama Kramar naglašava mističnu moć i ljepotu jezika te meditativno priziva sklad i ljepotu življenja. Njegov cjelokupni poetski ostvaraj jest otkrivenje i ostihovljenje onih vječnih istina, ali i dvojbi u čovjekovu biću, koje zatire kaotični, užurbani svijet. Poetika Ivana Kramara ekspandira u duhovnoj sintezi čovjeka i Boga. Tu je uporište Riječi, stvaralačkoga čina bliska Božjoj naravi, koji je u svojoj transcendenciji utjelovljenje bezuvjetne ljubavi za kojom moderni čovjek uporno traga na mračnim bespućima ovoga svijeta.

Ključne riječi: poezija; moderni stih; poetska slika; duhovnost; misaonost; ljubav; stil; jezik

$* * *$

Pjesnik Ivan Kramar u zbirkama Kameno more i Čavli zime polučuje duhovnost u suzvučju ljubavi prema svemu od Boga stvorenomu, ponajprije čovjeku, gdje je ona meditativna, u čvrstoj sprezi s istinom 
rođenom iz čista srca i subjektivne spoznaje. To je imanentna tendencija njegova duhovnog poetskog poslanja implicirana u modernome stilskom suzvučju religiozne misaonosti i emotivne intenzifikacije. Pjesme su u korelaciji s prirodom - uronjena duhovnost i ljubav u majestetični Božji dar ljudima kao nadahnuće i porinuće u beskrajnu i nedovoljno čuvanu ljepotu.

Bogatstvo njegova pjesničkog jezika očito je već u naslovima knjiga: Kameno more i Čavli zime, koji u genitivnoj metafori obuhvaćaju pjesnikov zavičaj i sadašnje mjesto boravka, konavoski krajolik. Zašto je more kameno i zima od čavala, otkriva sintagmatska simbolika u koju je snažno utkan emotivni naboj i vezanost za oba kraja. Naslovi knjiga u stilskome ekvivalentu sugestivno i slikovito dočaravaju i sukus pjesnikova života.

Modernost poetske riječi živo korespondira s lirskim i refleksivnim silnicama Kramarove poetike jer ona nije puka modernost u kojoj se gubi esencija poezije, nego je moderni stih srastao s impresijama i ekspresijama nutarnjega bivstva: Razlomit ću kolačić života, odjahati u svitanje bestjelesnosti, / naoružan samo nebom (Bestjelesnost). Upravo ta "naoružanost nebom“ jest primat duha, motiv koji je protega cijeloga pjesništva: „Pjesnik žudi samo za uzdizanjem i širenjem, za svijetom u koji se može protegnuti. Pjesnik samo traži način kako staviti glavu u nebo."

Neosporna je pjesnikova žeđ za transcendentnim bivstvom, koja se ostvaruje po Ljubavi, a dolazi iz ljubavi prema svakomu Božjem stvoru, poglavito u samoći: Susrećem sebe u sebi samom./ Kako je samoćadar! (Sutoni). U jednoj je svojoj književnoj ispovijesti napisao to i pjesnik i filozof G. Papini: „Ako sam velik, to je zato što sam imao snage biti samotnik.", a to su i životom potvrđivali mnogi umni ljudi i sveci. Breze u meni mjere himnu samoće (...) Ljubio sam svjetlost breze koja tiho šapće: / Sve ima kraj, osim Ljubavi... (Breze na putu za Burgkirchen). Tu Kramar zorno očituje podrijetlo poezije koja nadilazi zemaljske tvorbe, ona je božanskoga podrijetla, pa su nebo i ljubav u neraskidivoj svezi. I

Gilbert Keith Chesterton, Pravovjerje, Verbum, Split, 2015., str. 24. 
kada tjelesna ljubav ima prevagu i nadilazi strah od neba, kada se sedam smrtnih grijeha nadvije nad savjest, autor ih sublimira u pjesmu:

Sedam grijeha u pjesmu ću pretvoriti,

satkati pokrivač

samo za nas.

(...)

Na tvom dlanu otpočinuti,

tražiti onaj čudesni uvojak tvoje kose

dok s usana mi teče davno naučen stih.

(I kad šutim tebe ćutim)

Pjesma I kad šutim tebe ćutim i fonično je čuvstvena, ćutilna. Stilistički je intenzivirana zvučnim suglasnicima koji poentiraju misao i tvore ritmičnost. Pjesma je autoru bezgranični prostor slobode, ona može primiti sve naše emotivne silnice koje su u duhovnoj dimenzioniranosti preslika čovjekove neutažive čežnje za ljubavlju koja pokreće život.

Zato Kramar traga za još neizgovorenom riječju koja bi bila adekvat njegovoj bezgraničnoj ljubavi te se utječe Svevišnjemu:

Molim Gospodara,

da s neba spusti Riječ

neizgovorenu do sada,

da je prospem svuda oko tebe,

i njom kažem

sve.

(Riječ)

Kontemplativni molitveni ton i zaziv Gospodaru za do sada neizgovorenu Riječ potvrđuje pjesnikovu želju da svojoj ljubavi da onu aureolu koja u svome semantičkome diskursu ekspandira do mističnih duhovnih poniranja i nadilazi zbiljsku narav ljubavi. Ona je, prema Kramaru, slika cijeloga kozmosa kojom ravna Božja ruka postajući kontemplacijsko iskustvo: „Ali dok traje kontemplacijsko iskustvo, sva se ostala iskustva gube u trenu. Ona 'umiru' da se ponovo rode na višem stupnju života." ${ }_{2}$ Viši je stupanj života zasigurno poezija kao umjetnost koja u svojoj stvaralačkoj biti, a u okvirima riječi, postaje i osobita vrsta spoznaje. Spoznavši ljubav u njezinoj dubini, autor nudi i njezinu moć kojom želi izreći sve, a to sve nije tek obični oblik ljubavi, nego iskustvo

Thomas Merton, Nove sjemenke kontemplacije, Symposion, Split, 2014., str. 18. 
koje nadilazi zbiljske obzore. „Duša nije kadra sama po sebi spoznavati inteligibilni svijet, već jedino ukoliko je sjedinjena s Bogom. Čovjek uopće ne bi ništa spoznavao, da ga ne rasvjetljuje „sunce“ božje. Tako je eto i objektivna vrijednost vječnih istina i subjektivna spoznaja tih istina ontološki svoj osnov dobila u Bogu." ${ }^{\text {" }}$

Sjedinjujući dušu s Bogom, Kramar meditativno dolazi do molitve ljubavi, gdje je zbiljskoj čežnji korelat priroda, a opresivna zaživljenost prepuštena vječnosti: Kalemim tevječnošću, u ljubavi./ Želim da se ne bojiš gledati u zvijezde. I I da te nebo grli (Molitva). „Jer u jeziku pravoga pjesnika polučena je najviša sinteza i dano najčišće posredovanje i pomirenje suprotnosti. Tu se posebno pretvara u opće, opće u posebno. Svako doista pjesničko, napose svako čisto jezično oblikovanje pojavljuje se kao rješenje misterija svega duhovnog opstanka (...) Izražavajući neki osjećaj, pravi nam ga lirski genij daje kao nešto neponovljivo i jedinstveno, dotad nepostojeće.“4

Dubinu takve ljubavi može percipirati samo onaj tko u ontološkoj sferi prepoznaje bitak i ljubav kao Božji dar, kojemu možemo odgovoriti jedino po molitvi koja oslobađa od svih zemnih strahova i kadra je uzdignuti se i povezati našu ljubav s nebeskim visinama.

Supstancijalan motiv odanosti Bogu autor povremeno prekida svojim klonućima. To je onaj Isusov i naš kalvarijski hod nošenja životnoga križa pod kojim je i On padao: Došao sam, Isuse,/ skamenjena lica./ Koljena su se svila. (...) Ne daj da ova ljubav/ umre./ Ne daj! Imperativno ne daj ima kontekstualno emotivni naboj očaja i straha polučujući autorovu oslonjenost i sigurnost u Božju ljubav, što i jest jedino utočište i sigurnost u nesigurnosti i beznađu modernoga svijeta.

Još dublje klonuće nalazimo u pjesmi Bol u kojoj ljudska sloboda i hedonizam očito odvajaju čovjeka od Boga:

Stjepan Zimmermann, O biti spoznaje, Matica hrvatska, Zagreb, 2013., str. 31.

4 Ernest Cassirer, Prilozi filozofiji jezika, Matica hrvatska, Zagreb, 200o., str. 74. 
Koljena se svijaju,

ruke biju u prsa bijedna,

otima se tijelo, kruha bi, maslina

i vina, a Boga ne bi, a ne bi Boga.

Alternacijska igra riječima (a Boga ne bi, a ne bi Boga), koliko god bila ritmički originalan adekvat, arbitar je stilističke obilježenosti konotacijske misaone aktualnosti: moderni čovjek želi sve osim Boga. Istodobno je to i pjesnikov prosvjed protiv suvremena kondenzata bezbožna življenja.

I motive domoljublja, elegijske nostalgije za rodnom Bosnom pjesnik implementira u želju za još jednim putovanjem kroz rodni kraj od rođenja, kroz odrastanje, suobličujući se u slikovit krajolik i živeći njegovu veličajnost. Zato zaziva zemlju:

Porodi me opet, zemljo. Hoću biti planinski

potok. Hoću biti rijeka. Mirno teći

dolinom, nositi pročišćene

neistine. Biti kao ona sretan,

jer smo nikli u planinama.

(Zemlji)

Stilskim prebacivanjem i opkoračenjem Kramar naglašava mističnu moć i istinsku ljepotu prirode, ona pročišćava sve neistine u bistrini potoka tekući kroz doline. Njezin doticaj s nebom suznačeća je univerzalna misao o neraskidivoj vezi čovjekova života s prirodom kao učiteljicom i poticateljicom, afirmirajući potrebu vraćanja prirodi i njezinu očuvanju.

Dok pjesnika probadaju čavli zime, on smrznut, zaleđena srca, vidi: Svijet je vreća čavalal zime što kroz kosti prodirel u meso bez kapi krvi. Unatoč svemu nada postoji, ona je neugasla luč vjere kojom autor poentira pjesmu monostihom i grafički naglašava kurzivom: Svu sam nadu u Tebe stavio.

Stihovima, riječima koje nikoga ne ostavljaju ravnodušnim, ovaj vrsni pjesnik izvorište nalazi u Bogu koji je riječima dao moć stvaranja i trajanja. One nadilaze vrijeme i prostor, one su odsjaj vječnosti i oživotvorena istina, iskustvo i tradicija: 


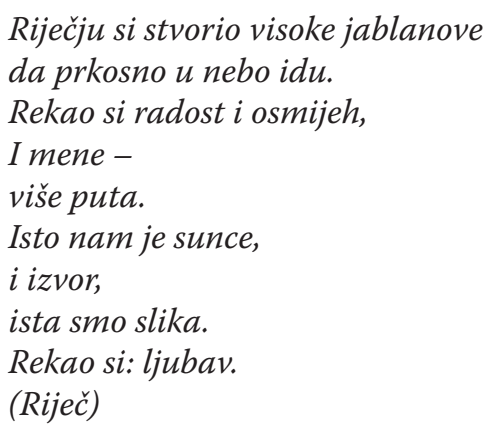

Poetika Ivana Kramara ekspandira u duhovnoj sintezi čovjeka i Boga. Tu je uporište Riječi, stvaralačkoga čina bliska Božjoj naravi, koja je u svojoj transcendenciji utjelovljenje bezuvjetne ljubavi za kojom moderni čovjek uporno traga na mračnim putovima ovoga svijeta.

Postmodernizam ovoga katoličkog pjesnika jest potvrda da duhovna poezija može akceptirati sve modernističke jezične elemente i pružiti čitatelju višu dimenziju umjetničkoga doživljaja u njegovoj emotivnoj i refleksivnoj percepciji. „Lijepo je na zemlji, dok ima na njoj pjesama niklih iz ljubavi“, zapisala je Kramarova prethodnica Sida Košutić, a lijepo je i što se nastavlja prekinuti kontinuitet hrvatske katoličke književnosti. Ivan Kramar, kao pjesnik duhovne lirike u hrvatskoj književnosti, zasigurno će i sam imati svoje sljedbenike. Njegov su cjelokupni poetski ostvaraj otkrivenje i opjesmjenjenje onih vječnih istina, ali i dvojbi u čovjekovu biću koje zatire kaotični, užurbani svijet. Demijurški oblikotvorenom, modernom poetikom autor daruje čitatelju esenciju života i sreće, približivši mu Božju narav i odnos spram čovjeka u duhovnome suzvučju ljubavi.

\section{Literatura}

- Cassirer, Ernest, Prilozi filozofiji jezika, Matica hrvatska, Zagreb, 2000.

- Chesterton, Gilbert Keith, Pravovjerje, Verbum, Split, 2015.

- Fridrich, Hugo, Struktura moderne lirike, Stvarnost, Zagreb, 1969. 
- Glavaš, Andrija Radoslav, Hrvatska književnost i duhovnost, izabrao i priredio Donat, Branimir, Dora Krupićeva, Zagreb, 1995.

- LonČARević, Vladimir, Književnost i hrvatski katolički pokret, Alfa, Zagreb, 2005.

- Merton, Thomas, Nove sjemenke kontemplacije, Symposion, Split, 2014.

- Mihanović, Nedjeljko, Tajanstvenost umjetničke riječi, Matica hrvatska, Zagreb, 2007.

- Paljetak, LuKo, „Govor na Brezovoj gori“, prolog u: KRAmar, Ivan, Kameno more, Naklada Ogranak Matice hrvatske u Podstrani, Podstrana, 2019., str. 5. - 8.

- Paljetak, Luko, „Vršenje naloga“, pogovor u: Kramar, Ivan, Čavli zime, Naklada Bošković, Pridvorje, 2020., str. 59. - 61.

- Pavletić, Vlatko, Poetika korelacija, Sveopća mreža odnosa, Školska knjiga, Zagreb, 2007.

- Pavletić, Vlatko, Trenutak vječnosti, Uvodenje u poetiku epifanija, Školska knjiga, Zagreb, 2008.

- Zimmermann, Stjepan, O biti spoznaje, Matica hrvatska, Zagreb, 2013. 
Original scientific article

Received on November 13, 2020

Accepted on April 7, 2021

Marina KlJajo-Radić

University of Mostar, Faculty of Humanities and Social Sciences

\section{SPIRITUAL HARMONY OF LOVE}

\section{Abstract}

Poetry in two new collections by Ivan Kramar is the modern poetry in which spirituality and love are strongly connected to nature and beauty. Poetic word vividly corresponds with lyrical and reflexive forces of Kramar's poetry since modern verse is fused with impressions and expressions of his internal essence. Kramar emphasizes mystical power and beauty of language and meditatively invokes harmony and beauty of living using stylistically simple, but carefully selected words and poetic images. His entire poetic realization is revelation and poetization of the eternal truth, but also doubts in human creature suppressed by chaotic, hectic world. van Kramar's poetics flourishes in the spiritual synthesis of God and human. There lies the mainstay of the Word, the creative act close to God's nature, who in his transcendence represents the embodiment of unconditional love which a modern man persistently seeks for in the dark wilderness of this world.

Keywords: poetry; modern verse; poetic image; spirituality; thoughtfulness; love; style; language 